\title{
Article \\ Major Depressive Disorder and Lifestyle: Correlated Genetic Effects in Extended Twin Pedigrees
}

\author{
Floris Huider ${ }^{1,2, *(D)}$, Yuri Milaneschi ${ }^{2,3}{ }^{\mathbb{D}}$, Matthijs D. van der Zee ${ }^{1}$, Eco J. C. de Geus ${ }^{1,2}$, Quinta Helmer ${ }^{1}$, \\ Brenda W. J. H. Penninx ${ }^{2,3}$ and Dorret I. Boomsma 1,2 (D) \\ 1 Department of Biological Psychology, Vrije Universiteit, 1081 BT Amsterdam, The Netherlands; \\ m.d.vander.zee@vu.nl (M.D.v.d.Z.); eco.de.geus@vu.nl (E.J.C.d.G.); q.helmer@vu.nl (Q.H.); \\ di.boomsma@vu.nl (D.I.B.) \\ 2 Amsterdam Public Health (APH) Research Institute, Amsterdam, The Netherlands; \\ y.milaneschi@ggzingeest.nl (Y.M.); b.penninx@amsterdamumc.nl (B.W.J.H.P.) \\ 3 Department of Psychiatry, Amsterdam UMC, Vrije Universiteit, 1081 HJ Amsterdam, The Netherlands \\ * Correspondence: f.huider@vu.nl; Tel.: +31-6-3744-3791
}

check for updates

Citation: Huider, F.; Milaneschi, Y.; van der Zee, M.D.; de Geus, E.J.C.; Helmer, Q.; Penninx, B.W.J.H.; Boomsma, D.I. Major Depressive Disorder and Lifestyle: Correlated Genetic Effects in Extended Twin Pedigrees. Genes 2021, 12, 1509. https://doi.org/10.3390/ genes12101509

Academic Editor: Jonathan Coleman

Received: 26 July 2021

Accepted: 22 September 2021

Published: 26 September 2021

Publisher's Note: MDPI stays neutral with regard to jurisdictional claims in published maps and institutional affiliations.

Copyright: (C) 2021 by the authors. Licensee MDPI, Basel, Switzerland. This article is an open access article distributed under the terms and conditions of the Creative Commons Attribution (CC BY) license (https:/ / creativecommons.org/licenses/by/ $4.0 /)$.

\begin{abstract}
In recent years, evidence has accumulated with regard to the ubiquity of pleiotropy across the genome, and shared genetic etiology is thought to play a large role in the widespread comorbidity among psychiatric disorders and risk factors. Recent methods investigate pleiotropy by estimating genetic correlation from genome-wide association summary statistics. More comprehensive estimates can be derived from the known relatedness between genetic relatives. Analysis of extended twin pedigree data allows for the estimation of genetic correlation for additive and non-additive genetic effects, as well as a shared household effect. Here we conduct a series of bivariate genetic analyses in extended twin pedigree data on lifetime major depressive disorder (MDD) and three indicators of lifestyle, namely smoking behavior, physical inactivity, and obesity, decomposing phenotypic variance and covariance into genetic and environmental components. We analyze lifetime MDD and lifestyle data in a large multigenerational dataset of 19,496 individuals by variance component analysis in the 'Mendel' software. We find genetic correlations for MDD and smoking behavior $\left(r_{\mathrm{G}}=0.249\right)$, physical inactivity $\left(r_{\mathrm{G}}=0.161\right)$, body-mass index $\left(r_{\mathrm{G}}=0.081\right)$, and obesity $\left(r_{\mathrm{G}}=0.155\right)$, which were primarily driven by additive genetic effects. These outcomes provide evidence in favor of a shared genetic etiology between MDD and the lifestyle factors.
\end{abstract}

Keywords: major depressive disorder; lifestyle; extended twin pedigree; variance decomposition; Mendel; genetic correlation; pleiotropy

\section{Introduction}

It is widely observed that multiple complex human traits tend to co-occur at the population-level. Klein and Riso (1993) presented a series of models explaining the causes of such comorbidity, which were extended by Neale and Kendler (1995) [1-3]. Explanations include chance and sampling bias, overlapping diagnostic criteria, multiformity where one disorder is an epiphenomenon of the other disorder and the co-morbid condition being an independent disorder. Complex traits can also have partly similar etiological processes, either environmental or genetic. The latter is defined as genetic pleiotropy [4], where one or multiple genes affect multiple traits, so that if the gene is segregating it causes simultaneous variation in the traits it affects. In recent years, evidence has accumulated with regard to the ubiquity of pleiotropy across the genome [5-7], and shared genetic etiology is thought to play a large role in the widespread comorbidity among psychiatric disorders $[8,9]$. Understanding genetic pleiotropy benefits our understanding of disease etiology, elucidating the relations among disorders as a function of sharing common genetic variant risk, as well as clarifying which traits and disorders are more distinct from one another [10]. 
In behavior genetics and genetic epidemiology, pleiotropy can be investigated by estimating the genetic correlation between traits. Similar to how the heritability of a trait encompasses the relative proportion of phenotypic variation in a population at a given time that is due to variation at the genetic level [11], the genetic correlation reflects the degree to which two traits share genetic variance [9]. The genetic correlation can be estimated through methods that analyze the co-segregation of traits in large extended pedigrees, such as those that are available in animal or plant breeding studies [4], or in human twin and family studies $[12,13]$. These methods employ the knowledge on genomic sharing from biometrical theory and base analyses on the cross-relative cross-trait covariance structure in bivariate phenotype data.

Major depressive disorder (MDD) is a complex, prevalent and burdensome condition with a well-established link with multiple lifestyle factors [14,15], including smoking behavior [16], physical (in)activity [17], and obesity [18]. Epidemiological data show smoking rate to be increased in clinically depressed individuals at twice the rate of the general population $[19,20]$, and both population-based studies as well as prospective cohort studies find elevated risk of MDD in those who smoke [21-23]. A similar pattern has been found for physical inactivity, with increased risk for depression in the physically inactive [24-26], and reduced rates of physical activity in clinically depressed individuals [27-29]. Finally, both cross-sectional $[30,31]$ and longitudinal studies [32-34] find evidence for bidirectional effects between depression and obesity.

The models proposed by Klein and Riso (1993) provide a range of explanations for these associations. In this paper we focus on exploring the shared genetic and environmental etiology of MDD and lifestyle traits, applying a bivariate biometrical approach to a large extended twin pedigree dataset of lifetime MDD and smoking behavior, physical inactivity, and obesity. We aimed to decompose phenotypic variance of these traits and their covariance with MDD into genetic and environmental components, thereby quantifying the degree to which comorbidity is explained by genetic and non-genetic contributions.

\section{Materials and Methods}

\subsection{Participants and Procedures}

We collected data on Major Depressive Disorder (MDD) and lifestyle variables in multi-generation twin families that are registered with the Netherlands Twin Register (NTR). Over the past three decades, the NTR recruited twins and their families for the study of human health and behavior. Methods of data collection include survey studies, experimental studies and biological sampling, as described in detail elsewhere [35]. Every two to three years, adult participants are approached with surveys pertaining to demographic information, phenotype data, and familial relations. The twelfth survey was collected in the period of 2015-2020 as part of the ongoing BIObanks Netherlands Internet Collective (BIONIC), a large consortium of which the NTR is a partner. BIONIC developed an online instrument to diagnose MDD in the Netherlands (detailed in [36]). In total, 21,823 surveys were collected by the NTR (1.2\% paper-based, $98.9 \%$ online), with valid lifetime MDD data for 21,243 individuals. Informed consent was obtained before proceeding to the questionnaire items. During a pilot phase in 2015 and shortly after, the survey was distributed as a paper-based version.

The survey was collected in twins and their relatives. Opposite-sex twins are always dizygotic. Zygosity in same-sex twins was determined from genotype data (55.5\%), or information from self-, parent-, or co-twin report. With this information, zygosity could be determined with certainty for $66.3 \%$ of twins. For the remaining twin pairs, zygosity was estimated from items on physical similarity, which we showed to capture DNA-confirmed zygosity $93 \%$ of the time [35]. Information on nuclear family and pedigree structure was obtained across multiple NTR databases (see [37]). We define a nuclear family as the combination of two parents and their offspring. As offspring proceed to become parents themselves, one individual can become part of multiple nuclear families. A pedigree refers to a collection of familial relations among individuals of, for example, a single nuclear 
family, or multiple nuclear families within large multi-generational pedigrees. The relations within a pedigree are not exclusively biological, as is the case for, e.g., spouses or adopted offspring.

\subsection{Phenotypic Measures}

BIONIC developed the Lifetime Depression Assessment Survey (LIDAS), an online self-report instrument for lifetime MDD ascertainment [36]. LIDAS is based on the Composite International Diagnostic Interview short form (CIDI-sf; [38]), and designed to efficiently identify lifetime MDD in population-based cohorts, in accordance with DSM-5 criteria. Bot et al. (2017) estimated sensitivity and specificity of LIDAS to be 85 and $80 \%$ respectively [36].

Lifetime major depressive disorder (MDD) status was determined in accordance with DSM-5 criteria from LIDAS data on nine symptoms [39]. Diagnostic criteria included having at least one of two core symptoms and having at least five of nine accessory symptoms, where symptoms were continuously present for a period of at least two weeks and caused significant disruption in daily functioning. Individuals without lifetime MDD (controls) were defined as having fewer than five symptoms, no core symptoms, and no significant disruption in daily functioning. Controls were further screened for the presence of other psychiatric disorders. If no diagnosis or treatment for a psychiatric disorder were reported, these individuals were included as 'screened controls'. Other controls $(n=1747)$ were excluded, together with individuals with unknown sex $(n=7)$, age $<16(n=3)$, and insufficient symptom data for diagnosis $(n=570)$.

Smoking behavior was recorded with three answers $(0=$ non-smoker, $1=$ current smoker, 2 = former smoker $)$ and was dichotomized $(0=$ 'never smoked', $1=$ 'ever smoked' $)$. Physical inactivity was recorded as the number of times per week respondents engaged in physical activities in their leisure time that caused sweating, with responses ranging from 0 ('None; zero times') to 1 ('Yes, once per week'), 2 ('Yes, twice per week'), 3 ('Yes, three times per week'), and 4 ('Yes, four times per week or more'). Answers were recoded into three levels of physical inactivity, so that $0=$ 'three or four times per week or more', $1=$ 'once or twice per week', and 2 = 'zero times per week'. Body-mass index (BMI) was defined as weight in $\mathrm{kg}$ divided by length in meters squared. Extreme BMI values were excluded if weight $<45 \mathrm{~kg}$ or $>200 \mathrm{~kg}$, height $<150 \mathrm{~cm}$ or $>220 \mathrm{~cm}$, or BMI $<15$ or $>50$. BMI data of 157 participants were retrieved from earlier surveys. For obesity, continuous BMI data were binned into categories so that $0=$ unaffected $(\mathrm{BMI}<30)$ and $1=$ obese $(\mathrm{BMI} \geq 30)$, in accordance with WHO criteria.

\subsection{Genetic Analyses}

To obtain indications of familial resemblance in lifetime MDD the lifestyle traits, we computed within- and cross-trait familial correlations for multiple pairs of relatives [40]. These included MZ (monozygotic) and DZ (dizygotic) twin pairs, siblings, spouses and parent-offspring, for all possible female-male combinations (e.g., brothers, sisters, fatherson, father-daughter, mother-son, mother-daughter), taking into account that an individual may contribute to multiple correlations (e.g., one mother may have two daughters in the dataset, creating two mother-daughter pairs).

Univariate and bivariate variance component analyses were conducted in the 'Mendel' software v. 16.0 [41]. Mendel is a versatile toolset for the statistical analysis of complex traits and incorporates an enhanced version of the variance components program 'Fisher' [42] for classical biometrical analyses. Mendel obtains maximum likelihood estimates of parameters and submodels can be compared through likelihood ratio tests [43]. Pedigree data with diverse types of relatives allows for the decomposition of phenotypic (co)variance into its underlying genetic and environmental components [44-46], especially when data of monozygotic twin pairs are included. Table 1 summarizes the genetic relatedness of relative pairs included in the pedigree, with their expected proportion of genetic sharing based on biometric theory [47]. 
Table 1. Familial relative pairs and expected proportion of genetic sharing.

\begin{tabular}{ccc}
\hline Pairing & Additive Genetic Sharing & Dominance Sharing \\
\hline Monozygotic twins & 1 & 1 \\
Dizygotic twins and non-twin & 0.5 & 0.25 \\
siblings & 0.375 & 0 \\
Three-quarter siblings & 0.25 & 0 \\
Half-siblings & 0.5 & 0 \\
Parent-offspring & 0.25 & 0 \\
Grandparent-grandchild & 0.25 & 0 \\
Aunt/uncle-niece/nephew & 0.125 & 0 \\
First cousins & 0.25 & 0 \\
First cousins with monozygotic & 0.25 & 0.0625 \\
twins as parents & 0 & 0 \\
Double first cousins & & \\
Spouses &
\end{tabular}

When size and complexity of pedigrees increase, specification of genetic relations among relatives can become increasingly difficult. The Mendel software allows inclusion of complex family (co)relations in large irregular pedigrees, at a cost of freedom in model specification. The specification of familial relations is achieved in a single input pedigree file, where one row corresponds to one individual, and where the first six columns contain all the required information to specify genetic relations: Family ID, Person ID, Father ID, Mother ID, Sex, and Twincode (to accommodate MZ twin pairs). All members of an (extended) pedigree share a family ID, while each individual in the pedigree has a unique personal identifier. Mendel requires either both parents or neither of them to be specified, and dummy parents were created to complete nuclear families where one parent was missing [37]. An additional field allows specification of which family members share a household. Sharing of a home environment may create resemblances over and above the resemblance that is explained by genetic relatedness. The definition of a household is flexible, in that sharing can be specified for an entire nuclear family or limited to specific relative pairs (e.g., siblings or spouses). Only one household variable can be specified, which then applies to all phenotypes in a model, so that careful consideration is required which definition is most appropriate for the phenotype, or phenotypes, in a bivariate model. We specified household sharing for all members of a nuclear family-spouses, their offspring, and the sibling relations between offspring-if offspring were under 24 years of age, 24 being the average age at which offspring leave their parental home in the Netherlands [48].

The Mendel software treats all phenotypes as quantitative. Categorical variables were scaled in such a way that higher categories reflected a higher score. In the genetic analyses, we consider obesity both as a dichotomous measure (BMI $<30$ vs. BMI $\geq 30$ ) and a continuous variable (BMI). BMI was log transformed to eliminate skewness. In all analyses, sex, age, and age ${ }^{2}$ were added to the linear regression model as fixed effects. Age $^{2}$ was included to account for non-linear effects of age on MDD. Age was standardized before its quadratic term was computed, effectively reducing their correlation to approximately zero [49].

The residual phenotypic (co)variances were decomposed into four variance components: additive genetic variance (A), non-additive genetic variance (D), household variance $(\mathrm{H})$, and unique environmental variance (E). The bivariate model is illustrated in Figure 1. Variance components and their standard errors were estimated by maximum likelihood and estimates of genetic and environmental correlation were obtained from the raw maximum likelihood covariance and variance component estimates (Box 1). 


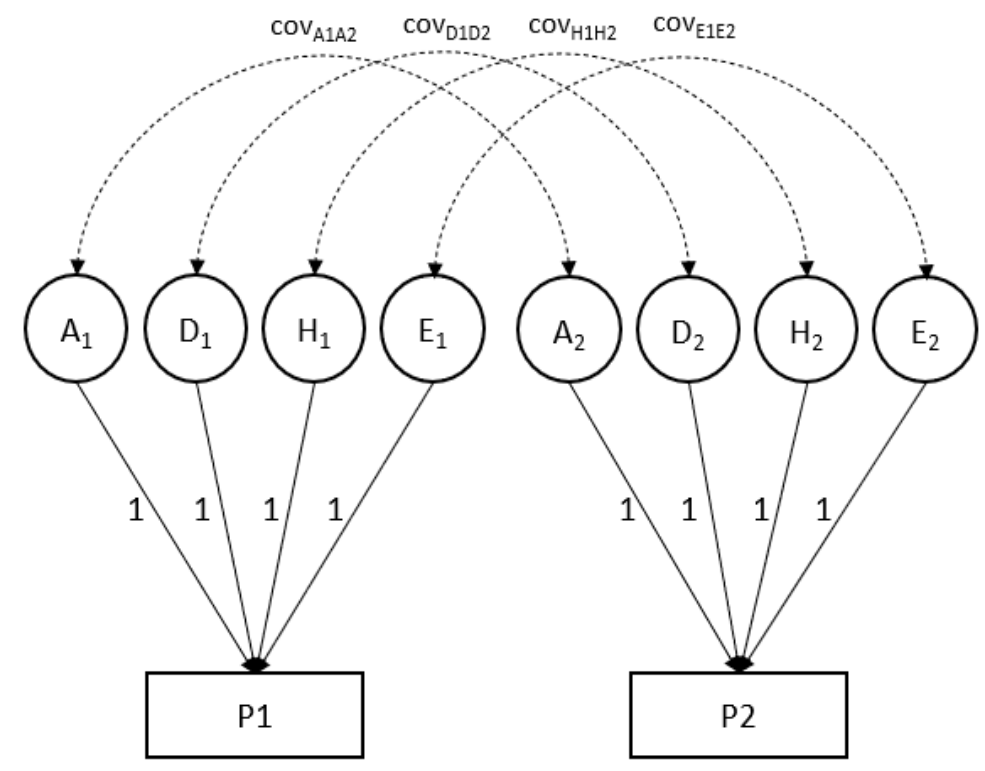

Figure 1. Illustration of a bivariate model, where the variance of each phenotype (P1 and P2) is due to four factors $(\mathrm{A}, \mathrm{D}, \mathrm{H}, \mathrm{E})$, and the covariance (cov) reflects the variance that is shared between the $\mathrm{A}, \mathrm{D}, \mathrm{H}$ and $\mathrm{E}$ factors. We estimated the variance of the latent factors and the covariances indicated in the figure.

Box 1. The Bivariate Model.

The bivariate model represented for an individual for two phenotypes (P1 and P2):

$\mathrm{P} 1=\mathrm{G} 1+\mathrm{NG} 1=\mathrm{A} 1+\mathrm{D} 1+\mathrm{H} 1+\mathrm{E} 1$

$\mathrm{P} 2=\mathrm{G} 2+\mathrm{NG} 2=\mathrm{A} 2+\mathrm{D} 2+\mathrm{H} 2+\mathrm{E} 2$

$\operatorname{Var}(\mathrm{P} 1)=\operatorname{Var}(\mathrm{G} 1)+\operatorname{Var}(\mathrm{NG} 1)$

$\operatorname{Var}(\mathrm{P} 2)=\operatorname{Var}(\mathrm{G} 2)+\operatorname{Var}(\mathrm{NG} 2)$

Broad-sense heritability $(\mathrm{P} 1)=\operatorname{Var}(\mathrm{G} 1) / \operatorname{Var}(\mathrm{P} 1)=H^{2}$

Narrow-sense heritability $(\mathrm{P} 1)=\operatorname{Var}(\mathrm{A} 1) / \operatorname{Var}(\mathrm{P} 1)=h^{2}$

Covar $(\mathrm{P} 1, \mathrm{P} 2)=$ Covar $(\mathrm{G} 1, \mathrm{G} 2)+$ Covar $(\mathrm{NG} 1, \mathrm{NG} 2)$

Phenotypic correlation: $r(\mathrm{P} 1, \mathrm{P} 2)=$ Covar $(\mathrm{P} 1, \mathrm{P} 2) / S D(\mathrm{P} 1) \times S D(\mathrm{P} 2)$

Genetic correlation: $r(\mathrm{G} 1, \mathrm{G} 2)=$ Covar $(\mathrm{G} 1, \mathrm{G} 2) / S D(\mathrm{G} 1) \times S D(\mathrm{G} 2)$;

where $P$ is an individual's phenotypic value (possibly a residual after correction for fixed effects of, e.g., age and sex), G is genotypic value and NG stands for non-genetic value. $\operatorname{Var}(\mathrm{P})$ is the variance of the phenotype (or the phenotypic residual); $\operatorname{var}(\mathrm{G})$ and $\operatorname{var}(\mathrm{NG})$ stand for genetic and non-genetic variance components (assuming no covariance of $\mathrm{G}$ and NG). $\mathrm{G}$ can be decomposed into additive genetic (A) and non-additive (dominance; $\mathrm{D}$ ) values; non-genetic influences can be distinguished into those that are common to members from the same household (called household effects $(\mathrm{H})$ in Mendel) and all other (unique; E) environmental effects.

The covariance between two phenotypes, here labeled P1 and P2 (e.g., MDD and smoking) likewise can be decomposed into genetic and non-genetic covariance. The correlation of P1 and P2 is obtained by scaling the phenotypic covariance by the product of the standard deviations of P1 and P2. Likewise, the genetic correlation is obtained by dividing the genetic covariance by the standard deviations of G1 and G2.

\section{Results}

\subsection{Phenotypic Overview}

The sample throughout the analyses consisted of 19,496 individuals (4300 lifetime MDD cases, 15,196 healthy controls), for which a descriptive overview is provided in Table 2. The sample consisted of 12,535 females $(64.3 \%)$ and 6961 males $(35.7 \%)$, with ages ranging from 16 to 92 and a mean of $41.75(S D=16.61)$. Females were on average 40.60 $(S D=15.98)$ years old, and males were on average $43.81(S D=15.98)$ years old. There were 10,799 nuclear families with at least one individual with phenotype data. The sample contained 9261 twins and 10,235 non-twin individuals. The 9261 twins $(47.2 \% \mathrm{MZ}, 52.8 \%$ 
DZ, $0.3 \%$ unknown zygosity) comprised 2375 complete twin pairs and 4482 unpaired twin individuals.

Table 2. Demographic and phenotypic descriptives of extended twin pedigree data. MDD = major depressive disorder.

\begin{tabular}{|c|c|c|c|c|c|c|}
\hline & \multirow[b]{2}{*}{$N$} & \multirow{2}{*}{$\begin{array}{l}\text { Age, Years } \\
\text { Mean (SD) }\end{array}$} & \multicolumn{2}{|c|}{ Sex } & \multicolumn{2}{|c|}{ MDD } \\
\hline & & & Female & Male & $\begin{array}{c}\text { Screened } \\
\text { Control }\end{array}$ & Case \\
\hline $\begin{array}{l}\text { Total } \\
\text { MDD, N (\%) }\end{array}$ & 19,496 & 41.75 (16.61) & $12,535(64.3 \%)$ & $6961(35.7 \%)$ & 15,196 & 4300 \\
\hline $\begin{array}{l}\text { Screened } \\
\text { control }\end{array}$ & $15,196(77.9 \%)$ & $41.72(16.93)$ & $9363(74.7 \%)$ & $5833(83.8 \%)$ & - & - \\
\hline $\begin{array}{l}\text { Case } \\
\text { Smoking } \\
\text { behavior, } N(\%)\end{array}$ & $4300(22.1 \%)$ & $41.82(15.43)$ & $3172(25.3 \%)$ & $1128(16.2 \%)$ & - & - \\
\hline $\begin{array}{l}\text { Never } \\
\text { smoked }\end{array}$ & $11,760(60.4 \%)$ & $37.76(15.98)$ & $7860(62.8 \%)$ & $3900(56.1 \%)$ & $9588(63.2 \%)$ & $2172(50.5 \%)$ \\
\hline $\begin{array}{l}\text { Ever smoked } \\
\text { Physical } \\
\text { inactivity, N (\%) }\end{array}$ & $7715(39.6 \%)$ & $47.80(15.70)$ & $4661(37.2 \%)$ & $3054(43.9 \%)$ & $5588(36.8 \%)$ & 2127 (49.5\%) \\
\hline Active & $5052(25.9 \%)$ & $37.96(17.06)$ & $2901(23.2 \%)$ & $2151(30.9 \%)$ & $4089(26.9 \%)$ & $963(22.4 \%)$ \\
\hline Moderate & $10,220(52.4 \%)$ & $42.53(16.10)$ & $6760(53.9 \%)$ & $3460(49.7 \%)$ & $7971(52.5 \%)$ & $2249(52.3 \%)$ \\
\hline Inactive & $4214(21.6 \%)$ & $44.36(16.52)$ & $2869(22.9 \%)$ & 1345 (19.3\%) & $3126(20.6 \%)$ & $1088(25.3 \%)$ \\
\hline $\begin{array}{l}\text { Body-mass } \\
\text { index * }\end{array}$ & & & & & & \\
\hline $\begin{array}{l}\text { Underweight } \\
(<18.5)\end{array}$ & $550(2.8 \%)$ & $25.99(12.46)$ & $393(3.2 \%)$ & $157(2.3 \%)$ & $411(2.7 \%)$ & $139(3.3 \%)$ \\
\hline $\begin{array}{l}\text { Normal } \\
\text { weight } \\
(18.5-24.9)\end{array}$ & $11,557(59.8 \%)$ & $38.28(16.51)$ & $7722(62.2 \%)$ & $3855(55.4 \%)$ & $9169(60.8 \%)$ & $2388(56.0 \%)$ \\
\hline $\begin{array}{l}\text { Overweight } \\
(25-29.9)\end{array}$ & $5459(28.2 \%)$ & $48.56(14.55)$ & $3053(24.6 \%)$ & $2406(34.7 \%)$ & $4252(28.2 \%)$ & $1207(28.3 \%)$ \\
\hline $\begin{array}{l}\text { Obesity } \\
(\geq 30)\end{array}$ & $1768(9.1 \%)$ & 48.97 (13.28) & $1240(10.0 \%)$ & $528(7.6 \%)$ & $1240(8.2 \%)$ & $528(12.4 \%)$ \\
\hline
\end{tabular}

* This categorization is for illustrative purposes; the analyses are of continuous BMI and obesity.

Figure 2 displays prevalence of lifetime MDD across demographic and lifestyle categories. As expected, lifetime MDD is higher in women than in men, and is more prevalent in middle-aged than in younger persons, but as we reported earlier [50], it is lower in the $60+$ age group. Figure 2 also shows a more unfavorable profile for all lifestyle traits in lifetime MDD cases than in controls. Affected persons smoke more often, they have a higher body weight and they are more often physically inactive. Correlations among the lifestyle variables were positive and weak: smoking behavior and physical inactivity $(r=0.046)$, smoking behavior and BMI $(r=0.163)$, physical inactivity and BMI $(r=0.126)$. 


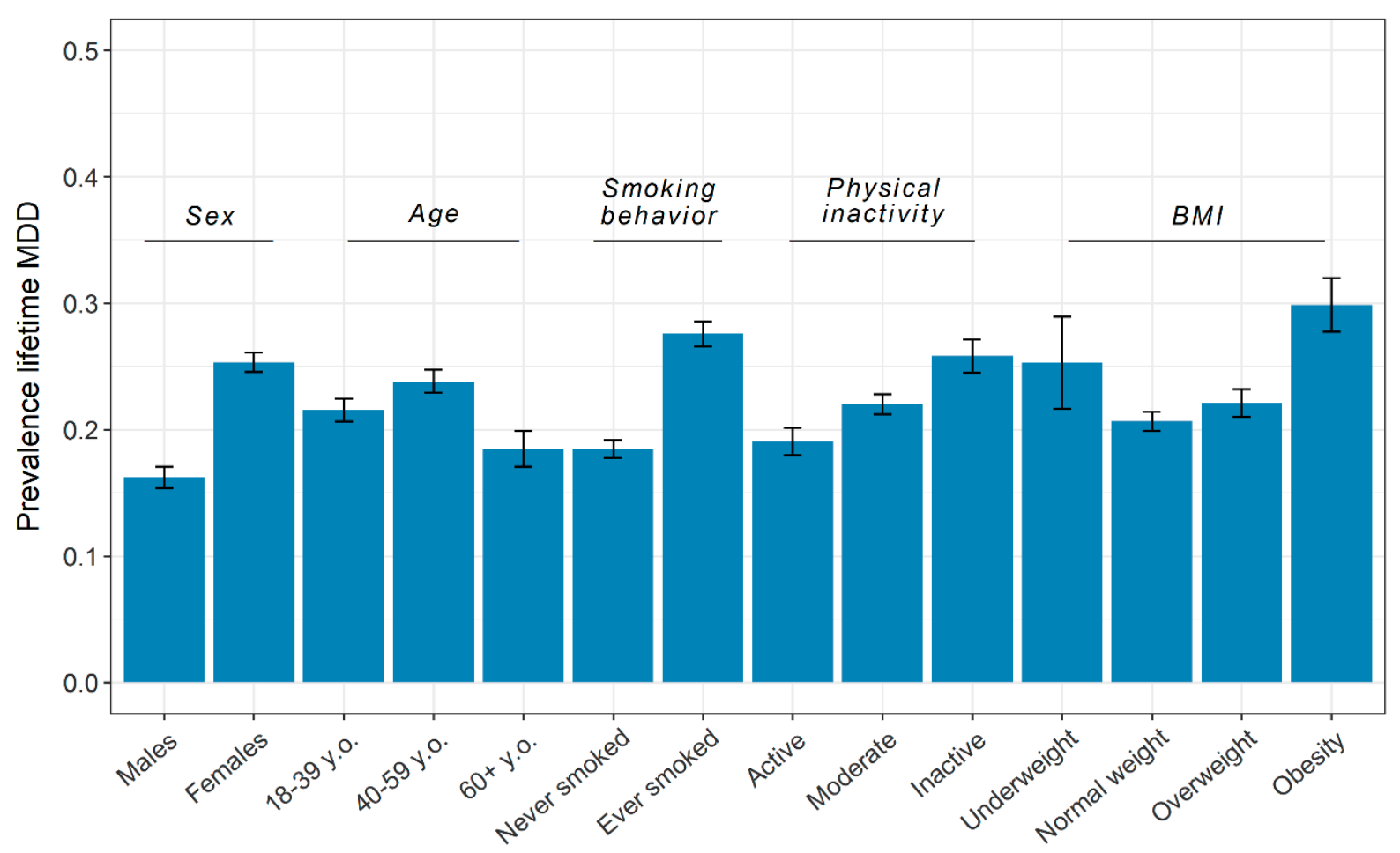

Figure 2. Prevalence of lifetime major depressive disorder across levels of demographic and lifestyle factors. MDD = major depressive disorder; BMI = body-mass index. Error bars reflect a 95\% confidence interval.

\subsection{Kinship Correlations}

We estimated within- and cross-trait kinship correlations for various relative pairings, listed in Table 3. If genetics contribute to familial similarity, we expect phenotypic kinship correlations to decrease with decreasing genetic similarity among more distant kinship pairs. We observed a consistent pattern where relatives who were genetically more similar showed higher within-trait correlations across all considered traits. For example, the within-trait correlation of lifetime MDD equaled $r=0.439$ and $r=0.299$ in MZ males and females and ranged between $r=0.072$ and $r=0.303$ in DZ and sibling pairs, suggesting that a genetic component contributed to familial resemblance of MDD. Table 3 also contains the spousal correlations for two groups, i.e., parents of twins and twins with their own spouses. Parents of twins were older (median age $=44$ years) than twins and their spouses (median age $=27$ years). We computed spousal correlations separately for these groups. There was little evidence for differences in resemblance between the younger and older spouse groups. For MDD, spousal correlations were small ( $r=0.105$ vs. $r=0.050$ ). The largest difference between the two age groups for BMI $(r=0.272$ in twins and their spouses vs. $r=0.185$ in parents of twins). Cross-trait correlations between MDD and smoking showed a pattern where MZ twin correlations were larger than those in first-degree relatives, suggestive of a genetic contribution to their comorbidity. Such patterns were less evident for the other trait combinations. 
Table 3. Within- and cross-trait kinship correlation estimates for various kinships with valid lifetime major depressive disorder data in the extended twin pedigree. $\mathrm{MDD}=$ major depressive disorder; $\mathrm{PI}=$ physical inactivity; $\mathrm{BMI}=$ body-mass index; $\mathrm{MZ}=$ monozygotic twins; $\mathrm{DZ}=$ dizygotic twins.

\begin{tabular}{|c|c|c|c|c|c|c|c|c|c|c|c|c|c|}
\hline \multirow[b]{2}{*}{ Kinship } & \multicolumn{5}{|c|}{$r(n)$} & \multicolumn{4}{|c|}{$\begin{array}{l}r \text { between MDD Relative 1; Lifestyle } \\
\text { Relative } 2\end{array}$} & \multicolumn{4}{|c|}{$\begin{array}{c}r \text { between Lifestyle Relative 1; MDD } \\
\text { Relative } 2\end{array}$} \\
\hline & MDD & Smoking & PI & BMI & Obesity & Smoking & PI & BMI & Obesity & Smoking & PI & BMI & Obesity \\
\hline $\begin{array}{l}\text { Spouse } \\
\text { (par- } \\
\text { ents) }\end{array}$ & $\begin{array}{c}0.050 \\
(1570)\end{array}$ & $\begin{array}{c}0.259 \\
(1563)\end{array}$ & $\begin{array}{c}0.167 \\
(1568)\end{array}$ & $\begin{array}{c}0.185 \\
(1556)\end{array}$ & $\begin{array}{c}0.096 \\
(1556)\end{array}$ & 0.009 & 0.023 & -0.004 & 0.001 & -0.004 & 0.021 & -0.018 & -0.020 \\
\hline $\begin{array}{l}\text { Spouse } \\
\text { (twins) }\end{array}$ & $\begin{array}{l}0.105 \\
(386)\end{array}$ & $\begin{array}{l}0.227 \\
(384)\end{array}$ & $\begin{array}{l}0.155 \\
(384)\end{array}$ & $\begin{array}{l}0.272 \\
(384)\end{array}$ & $\begin{array}{l}0.061 \\
(384)\end{array}$ & 0.047 & 0.017 & 0.014 & 0.065 & -0.048 & 0.025 & -0.107 & -0.094 \\
\hline $\begin{array}{l}\mathrm{MZ} \\
\text { males }\end{array}$ & $\begin{array}{l}0.439 \\
(342)\end{array}$ & $\begin{array}{l}0.505 \\
(341)\end{array}$ & $\begin{array}{l}0.411 \\
(342)\end{array}$ & $\begin{array}{l}0.726 \\
(339)\end{array}$ & $\begin{array}{l}0.548 \\
(339)\end{array}$ & 0.085 & 0.008 & 0.003 & 0.034 & 0.164 & 0.031 & -0.051 & 0.001 \\
\hline $\begin{array}{l}\text { MZ fe- } \\
\text { males }\end{array}$ & $\begin{array}{l}0.299 \\
(986)\end{array}$ & $\begin{array}{l}0.561 \\
(983)\end{array}$ & $\begin{array}{l}0.376 \\
(984)\end{array}$ & $\begin{array}{l}0.764 \\
(979)\end{array}$ & $\begin{array}{l}0.490 \\
(979)\end{array}$ & 0.132 & 0.043 & 0.019 & 0.036 & 0.132 & 0.051 & 0.045 & 0.054 \\
\hline $\begin{array}{c}\mathrm{DZ} \\
\text { males }\end{array}$ & $\begin{array}{l}0.303 \\
(195)\end{array}$ & $\begin{array}{l}0.260 \\
(194)\end{array}$ & $\begin{array}{l}0.212 \\
(194)\end{array}$ & $\begin{array}{l}0.224 \\
(193)\end{array}$ & $\begin{array}{l}-0.027 \\
(193)\end{array}$ & -0.006 & 0.097 & -0.022 & -0.094 & 0.152 & 0.048 & -0.053 & 0.130 \\
\hline $\begin{array}{l}\mathrm{DZ} \text { fe- } \\
\text { males }\end{array}$ & $\begin{array}{l}0.072 \\
(410)\end{array}$ & $\begin{array}{l}0.246 \\
(410)\end{array}$ & $\begin{array}{l}0.194 \\
(409)\end{array}$ & $\begin{array}{l}0.293 \\
(400)\end{array}$ & $\begin{array}{l}0.045 \\
(400)\end{array}$ & 0.064 & 0.047 & 0.034 & 0.027 & 0.046 & 0.112 & 0.005 & 0.002 \\
\hline $\begin{array}{l}\text { DZ op- } \\
\text { posite } \\
\text { sex }\end{array}$ & $\begin{array}{l}0.139 \\
(450)\end{array}$ & $\begin{array}{l}0.223 \\
(449)\end{array}$ & $\begin{array}{l}0.104 \\
(449)\end{array}$ & $\begin{array}{l}0.299 \\
(443)\end{array}$ & $\begin{array}{l}0.139 \\
(443)\end{array}$ & 0.057 & -0.016 & 0.060 & 0.112 & 0.119 & -0.012 & 0.022 & 0.013 \\
\hline $\begin{array}{l}\text { Mother- } \\
\text { Daughter }\end{array}$ & $\begin{array}{l}0.105 \\
(2440)\end{array}$ & $\begin{array}{l}0.128 \\
(2437)\end{array}$ & $\begin{array}{l}0.135 \\
(2440)\end{array}$ & $\begin{array}{c}0.296 \\
(2409)\end{array}$ & $\begin{array}{c}0.161 \\
(2409)\end{array}$ & -0.005 & 0.029 & 0.049 & 0.051 & 0.052 & 0.024 & 0.030 & 0.023 \\
\hline $\begin{array}{l}\text { Mother- } \\
\text { Son }\end{array}$ & $\begin{array}{c}0.092 \\
(1324)\end{array}$ & $\begin{array}{c}0.173 \\
(1322)\end{array}$ & $\begin{array}{c}0.039 \\
(1324)\end{array}$ & $\begin{array}{c}0.205 \\
(1314)\end{array}$ & $\begin{array}{c}0.092 \\
(1314)\end{array}$ & 0.042 & -0.007 & -0.040 & -0.027 & 0.035 & -0.014 & 0.002 & 0.003 \\
\hline $\begin{array}{l}\text { Father- } \\
\text { Daughter }\end{array}$ & $\begin{array}{c}0.111 \\
(1700)\end{array}$ & $\begin{array}{c}0.113 \\
(1699)\end{array}$ & $\begin{array}{c}0.148 \\
(1699)\end{array}$ & $\begin{array}{c}0.229 \\
(1680)\end{array}$ & $\begin{array}{c}0.134 \\
(1680)\end{array}$ & -0.012 & 0.017 & 0.031 & 0.053 & 0.022 & 0.065 & 0.010 & -0.011 \\
\hline $\begin{array}{l}\text { Father- } \\
\text { Son }\end{array}$ & $\begin{array}{c}0.103 \\
(1007)\end{array}$ & $\begin{array}{c}0.201 \\
(1007)\end{array}$ & $\begin{array}{c}0.110 \\
(1007)\end{array}$ & $\begin{array}{c}0.253 \\
(1001)\end{array}$ & $\begin{array}{c}0.086 \\
(1001)\end{array}$ & 0.077 & -0.004 & 0.0003 & -0.027 & -0.010 & 0.027 & -0.004 & 0.017 \\
\hline $\begin{array}{l}\text { Brother- } \\
\text { Brother }\end{array}$ & $\begin{array}{l}0.235 \\
(202)\end{array}$ & $\begin{array}{l}0.307 \\
(201)\end{array}$ & $\begin{array}{l}0.238 \\
(201)\end{array}$ & $\begin{array}{l}0.315 \\
(197)\end{array}$ & $\begin{array}{l}0.112 \\
(197)\end{array}$ & -0.041 & -0.026 & 0.025 & -0.025 & 0.158 & 0.130 & 0.016 & 0.157 \\
\hline $\begin{array}{l}\text { Brother- } \\
\text { Sister }\end{array}$ & $\begin{array}{c}0.143 \\
(1128)\end{array}$ & $\begin{array}{l}0.176 \\
(1127)\end{array}$ & $\begin{array}{c}0.080 \\
(1126)\end{array}$ & $\begin{array}{c}0.256 \\
(1120)\end{array}$ & $\begin{array}{c}0.121 \\
(1120)\end{array}$ & -0.010 & 0.020 & 0.066 & 0.077 & 0.089 & 0.031 & 0.015 & -0.031 \\
\hline $\begin{array}{l}\text { Sister- } \\
\text { Sister }\end{array}$ & $\begin{array}{l}0.091 \\
(579)\end{array}$ & $\begin{array}{l}0.296 \\
(578)\end{array}$ & $\begin{array}{l}0.206 \\
(578)\end{array}$ & $\begin{array}{l}0.334 \\
(564)\end{array}$ & $\begin{array}{l}0.169 \\
(564)\end{array}$ & 0.131 & 0.058 & 0.015 & -0.019 & 0.072 & 0.088 & 0.041 & -0.028 \\
\hline
\end{tabular}

\subsection{Variance Component Analyses}

We first conducted a series of univariate variance component analyses, decomposing the phenotypic variances of lifetime MDD, smoking behavior, physical inactivity, BMI and obesity into four variance components: additive genetic variance (A), non-additive genetic variance $(D)$, household variance $(H)$, and unique environmental variance $(E)$. Maximum likelihood estimates of variance components and their standard errors are listed in Table 4. All variance component estimates of lifetime MDD and lifestyle variables were significantly larger than zero, indicating contributions of genetic and non-genetic factors to all traits. Estimates of broad-sense heritability $\left(\mathrm{H}^{2}\right)$, that is, the sum of the additive and non-additive genetic variance components divided by the total phenotypic variance, were $H^{2}=0.335$ in MDD, $H^{2}=0.550$ in smoking behavior, $H^{2}=0.318$ in physical inactivity, $H^{2}=0.725$ in BMI and $H^{2}=0.647$ in obesity. Thus, these broad-sense estimates combine the influence of additive and non-additive genetic effects. The magnitude of non-additive genetic effects (dominance; D) varied across traits. The magnitude of household effects $(\mathrm{H})$ was consistently low but significant across traits, suggesting that shared household effects play a minor role in the phenotypic resemblance among relatives who live together. A large proportion of phenotypic variance was due to unique environment i.e., individual-specific environmental factors $(E)$ and measurement error, particularly in lifetime $\operatorname{MDD}(E=0.618)$ and physical inactivity $(\mathrm{E}=0.574)$. 
Table 4. Maximum-likelihood (co)variance component estimates and derived correlation estimates between major depressive disorder and four lifestyle factors: smoking behavior, physical inactivity, body-mass index, and obesity. All models included sex, age, and age ${ }^{2}$ as fixed covariates. MDD = major depressive disorder; PI = physical inactivity; BMI = body-mass index; VC = variance component; se = standard error; $\mathrm{A}=$ additive genetic component; $\mathrm{D}=$ non-additive genetic component; $\mathrm{H}$ = household component; $\mathrm{E}$ = unique environment component.

\begin{tabular}{|c|c|c|c|c|c|c|c|c|c|}
\hline \multirow[t]{2}{*}{ Model } & \multirow[t]{2}{*}{$N$} & \multicolumn{4}{|c|}{ Raw VC (se) } & \multicolumn{4}{|c|}{ Standardized VC } \\
\hline & & A & D & $\mathbf{H}$ & E & $\mathbf{A}$ & D & $\mathbf{H}$ & E \\
\hline MDD & 19,496 & $\begin{array}{c}0.032 \\
(0.005)\end{array}$ & $\begin{array}{c}0.025 \\
(0.006)\end{array}$ & $\begin{array}{c}0.008 \\
(0.003)\end{array}$ & $\begin{array}{c}0.105 \\
(0.004)\end{array}$ & 0.189 & 0.146 & 0.048 & 0.618 \\
\hline Smoking & 19,475 & $\begin{array}{c}0.033 \\
(0.007)\end{array}$ & $\begin{array}{c}0.088 \\
(0.007)\end{array}$ & $\begin{array}{c}0.028 \\
(0.003)\end{array}$ & $\begin{array}{c}0.071 \\
(0.003)\end{array}$ & 0.149 & 0.401 & 0.127 & 0.323 \\
\hline PI & 19,486 & $\begin{array}{c}0.038 \\
(0.014)\end{array}$ & $\begin{array}{c}0.109 \\
(0.016)\end{array}$ & $\begin{array}{c}0.049 \\
(0.007)\end{array}$ & $\begin{array}{c}0.264 \\
(0.010)\end{array}$ & 0.082 & 0.236 & 0.108 & 0.574 \\
\hline BMI & 19,334 & $\begin{array}{c}0.009 \\
(0.001)\end{array}$ & $\begin{array}{c}0.006 \\
(0.001)\end{array}$ & $\begin{array}{c}0.002 \\
(0.0003)\end{array}$ & $\begin{array}{c}0.004 \\
(0.0002)\end{array}$ & 0.422 & 0.303 & 0.095 & 0.175 \\
\hline Obesity & 19,334 & $\begin{array}{c}0.015 \\
(0.003)\end{array}$ & $\begin{array}{l}0.0384 \\
(0.003)\end{array}$ & $\begin{array}{c}0.009 \\
(0.001)\end{array}$ & $\begin{array}{c}0.021 \\
(0.001)\end{array}$ & 0.185 & 0.462 & 0.107 & 0.246 \\
\hline
\end{tabular}

Next, bivariate analyses were conducted for MDD and each of the lifestyle factors. Covariance component and correlation estimates are listed in Table 5. We found positive genetic correlations $\left(r_{\mathrm{G}}\right)$ between lifetime MDD and smoking behavior $\left(r_{\mathrm{G}}=0.249\right)$, physical inactivity $\left(r_{\mathrm{G}}=0.161\right)$, BMI $\left(r_{\mathrm{G}}=0.081\right)$, and obesity $\left(r_{\mathrm{G}}=0.155\right)$. The positive directions of these genetic correlations indicate that the genetic factors that are shared between traits tend to influence both trait values in the same direction; the shared genetic etiology contributes either to an increase or a decrease in both traits, but not an increase in one and a decrease in the other.

Table 5. Maximum-likelihood (co)variance component estimates and derived correlation estimates between major depressive disorder and four lifestyle factors: smoking behavior, physical inactivity, body-mass index, and obesity. All models included sex, age, and age ${ }^{2}$ as fixed covariates. $\mathrm{MDD}=$ major depressive disorder; $\mathrm{PI}=$ physical inactivity; $\mathrm{BMI}=$ body-mass index; $\mathrm{VC}$ = variance component; se = standard error; $\mathrm{A}=$ additive genetic component; $\mathrm{D}=$ non-additive genetic component; $\mathrm{H}=$ household component; $\mathrm{E}=$ unique environment component; $\mathrm{G}=$ genetic component, where $\mathrm{A}+\mathrm{D}=\mathrm{G}$.

\begin{tabular}{|c|c|c|c|c|c|c|c|c|c|c|}
\hline \multirow[t]{2}{*}{ Model } & \multirow[t]{2}{*}{$N$} & \multicolumn{4}{|c|}{ Raw Covariance (se) } & \multicolumn{5}{|c|}{ Correlation } \\
\hline & & $\mathbf{A}$ & D & $\mathbf{H}$ & $\mathbf{E}$ & A & $\mathbf{D}$ & G & $\mathbf{H}$ & $\mathbf{E}$ \\
\hline $\begin{array}{l}\text { Smoking and } \\
\text { MDD }\end{array}$ & 19,475 & $\begin{array}{l}0.008 \\
(0.004)\end{array}$ & $\begin{array}{c}0.013 \\
(0.005)\end{array}$ & $\begin{array}{c}0.002 \\
(0.002)\end{array}$ & $\begin{array}{l}-0.001 \\
(0.003)\end{array}$ & 0.238 & 0.278 & 0.249 & 0.158 & -0.006 \\
\hline PI and MDD & 19,486 & $\begin{array}{c}0.012 \\
(0.006)\end{array}$ & $\begin{array}{c}0.002 \\
(0.007)\end{array}$ & $\begin{array}{c}0.001 \\
(0.003)\end{array}$ & $\begin{array}{l}-0.004 \\
(0.005)\end{array}$ & 0.357 & 0.044 & 0.161 & 0.061 & -0.022 \\
\hline BMI and MDD & 19,334 & $\begin{array}{c}0.003 \\
(0.001)\end{array}$ & $\begin{array}{l}-0.0003 \\
(0.0013)\end{array}$ & $\begin{array}{c}0.001 \\
(0.001)\end{array}$ & $\begin{array}{c}0.0001 \\
(0.0007)\end{array}$ & 0.160 & -0.024 & 0.081 & 0.146 & 0.005 \\
\hline Obesity and MDD & 19,334 & $\begin{array}{c}0.006 \\
(0.003)\end{array}$ & $\begin{array}{c}0.003 \\
(0.003)\end{array}$ & $\begin{array}{c}-0.0002 \\
(0.001)\end{array}$ & $\begin{array}{l}-0.002 \\
(0.002)\end{array}$ & 0.256 & 0.093 & 0.155 & -0.023 & -0.043 \\
\hline
\end{tabular}

Unique to an extended twin pedigree design, we were able to delineate genetic correlations into additive and non-additive genetic components. Estimates of additive genetic correlations $\left(r_{\mathrm{A}}\right)$ tended to be larger than non-additive genetic correlations $\left(r_{\mathrm{D}}\right)$, and most non-additive genetic covariances included zero in their $95 \%$ confidence interval (10.96 times the standard error). Additive and non-additive genetic components were typically correlated in the same (positive) direction. The genetic correlation with lifetime MDD was stronger for obesity $\left(r_{\mathrm{G}}=0.155\right)$ than for BMI $\left(r_{\mathrm{G}}=0.081\right)$, suggesting that the genetic correlation of body weight and lifetime MDD may be stronger when differentiating between normal and more extreme cases of body weight. 
Household components for lifetime MDD and lifestyle were not correlated, as household covariances did not reach significance for any of the trait combinations. A correlation between household components would suggest that some aspects of sharing a household can cause similar changes in two traits. Some estimates of $r_{\mathrm{H}}$, such as those between MDD and smoking behavior $\left(r_{\mathrm{H}}=0.158\right)$, and MDD and BMI $\left(r_{\mathrm{H}}=0.146\right)$, were larger than others. However, the main effects of household, defined as the contribution of non-genetic factors that increase familial resemblance, were very modest to begin with. Finally, unique environmental effects explained considerable trait variance, but correlations between unique environmental components $\left(r_{\mathrm{E}}\right)$ were close to zero, ranging from $r_{\mathrm{E}}=0.005$ in BMI to $r_{\mathrm{E}}$ $=-0.043$ in obesity. This suggests that although unique environmental effects can have a large effect on individual differences in both lifetime MDD and lifestyle variables, few of these effects are shared across the traits considered here. Estimates of $\mathrm{E}$ incorporate non-systematic effects and measurement error, which likely are uncorrelated, and so the low estimates of $r_{\mathrm{E}}$ are not unexpected.

\section{Discussion}

We sought to quantify the genetic and non-genetic contributions to comorbidity between lifetime Major Depressive Disorder (MDD) and three indicators of lifestyle: smoking behavior, physical inactivity, and obesity. We conducted bivariate variance component analyses in data of twins and extended family relations from the Netherlands Twin Register, decomposing phenotypic variance and covariance into additive genetic (A), non-additive genetic (D), household (H), and unique environmental (E) components. Covariance estimates between trait components were scaled by their respective variance estimates to obtain estimates of genetic and environmental correlations. We found genetic correlations between MDD and all lifestyle factors. In contrast, there was little evidence for correlations between household or unique environmental effects. That is, phenotypic relations between MDD and the lifestyle traits were primarily driven by genetic effects, with considerable additive genetic correlations $\left(r_{\mathrm{A}}\right)$ for all MDD-lifestyle combinations.

We found a broad-sense heritability for MDD of $33.5 \%$, in line with previous estimates from twin data (34-37\%) [51,52], and register-based data with reconstructed extended familial relationships (25-32\%) [53,54]. The most current SNP- $h^{2}$ estimate for MDD, defined as the percentage of phenotypic variation that is due to variation in common single nucleotide polymorphisms (SNPs), equals 8.9\% [55,56]. Environmental effects on MDD were primarily individual-specific $(\mathrm{E} ; 62 \%)$, as is consistent with the literature. In contrast to many other studies, we observed that common environment, here defined as household sharing $(\mathrm{H})$, played a minor but significant role in explaining individual differences in MDD, with around $5 \%$ of variance accounted for by these effects. Also of interest is that few twin and family studies of MDD report estimates of non-additive effects (D), whereas we find roughly equal additive and non-additive genetic contributions to the broad-sense heritability (making up $18.9 \%$ and $14.6 \%$ of total phenotypic variance, respectively). Similar increases in non-additive genetic effects have been reported in extended twin pedigree designs for other traits (e.g., $[40,57,58]$ ), and may result from increases in statistical power or the ability to model additional variance components. We note that the inclusion of non-twin family relations introduces age differences within relative pairs, which might mimic non-additive effects when, for example, age differences result in reduced resemblance in parent-offspring pairs, but not in DZ twin or sibling pairs (Table 1). However, a longitudinal analysis of depression data found no evidence for genetic innovation, i.e., after adolescence there was no evidence that different genes were expressed at later ages, and so we do not expect to see artificial non-additivity [59].

Turning to the bivariate analyses of MDD and lifestyle factors, we may also compare our results of modest genetic correlations with findings from twin and SNP-based studies. Findings from twin studies vary with regard to the genetic correlation between MDD and smoking behavior. Some studies report moderate to large genetic correlations in the range of $r_{\mathrm{G}}=0.25-0.56[21,60,61]$, whereas others find no evidence for a genetic correlation [62,63], 
or instead find evidence for a shared environmental etiology [64]. Similar to SNP- $h^{2}$, genetic correlation estimates can be derived from molecular data (SNP- $r_{\mathrm{G}}$ ) [9]. The most recent $\mathrm{SNP}-r_{\mathrm{G}}$ estimate between MDD and 'ever vs. never smoked' equals SNP- $r_{\mathrm{G}}=0.314(95 \%$ CI: 0.242-0.385) [55]. Our estimate $\left(r_{\mathrm{G}}=0.249\right)$ lies at the low end of this confidence interval. For physical inactivity, findings from an earlier bivariate twin study suggest a moderate genetic correlation between depressive symptoms and exercise behavior $\left(r_{\mathrm{G}}=-0.230\right)$ [65], and a more recent study finds a negative $\mathrm{SNP}-r_{\mathrm{G}}$ between MDD and physical activity of $\mathrm{SNP}-r_{\mathrm{G}}=-0.100$ [29]. We find a genetic correlation in the expected opposite direction, as we use physical inactivity as the outcome, that is somewhat in between these two estimates $\left(r_{\mathrm{G}}=0.161\right)$. Finally, twin studies provide some evidence for a shared genetic etiology between MDD and BMI or obesity. Afari et al. (2010) applied a bivariate twin method to depression and obesity data and found a genetic correlation of $r_{\mathrm{G}}=0.120$ [66]. However, Choy et al. report a significant proportion of shared environmental factors between depression and BMI, but no significant genetic correlation [67]. The most recent SNP- $r_{G}$ estimate for depression and BMI equals SNP- $r_{\mathrm{G}}=0.076$, and those between depression and obesity equal SNP- $r_{G}=0.086,0.082$, and 0.168 for obesity class 1,2 , and 3 , respectively [55]. Our estimates of genetic correlation with MDD are similar to these SNP- $r_{\mathrm{G}}$ estimates, with $r_{\mathrm{G}}=0.081$ for BMI and $r_{\mathrm{G}}=0.155$ for obesity.

These results should be viewed in light of some limitations. First, the extended twin pedigree design relies on a number of assumptions which, when violated, could bias parameter estimates [58]. However, the method is a statistically powerful approach [68] that relies on fewer assumptions than, e.g., the classical twin design, and has been suggested to be more robust to violations of these assumptions [69]. The possibility to analyze all family relations from large extended pedigrees in the Mendel software came at a cost of restrictions in model specification, so that some effects (e.g., sex-dependent heritability, gene-environment interaction or correlation) could not be modeled. Likewise, only a single definition of household effects could be specified for two traits in a bivariate model. Ideally, we would have specified a unique and best-suiting definition of household separately for each trait and possibly for different sets of relatives. We also note that household is a form of the common environment that may not take into account any lasting effects of having shared a household. This may have contributed to the low estimates of household effects in univariate models, although modest estimates for shared environmental effects are consistent with the literature. Further, we recognize that the lifestyle factors we consider are not independent from each other, although correlations between them were weak.

Interpreting these findings requires a consideration of the mechanisms that can underlie phenotypic relations at the population level, and the mechanisms that can underlie correlations at the genetic level. Well-established associations exist for MDD and smoking [16], physical inactivity $[25,70]$, and BMI and obesity [18,32], but findings regarding the underlying mechanisms tend to support different functional mechanisms. These mechanisms include causal effects from one trait to another, bidirectional causality between two traits, or confounding by a third set of factors, such as a shared genetic or environmental etiology (e.g., [1,60]). Likewise, a genetic correlation between phenotypes can still indicate multiple mechanisms that include causality and pleiotropy [71,72]. One distinction is that of horizontal and vertical pleiotropy. In horizontal pleiotropy, a gene affects multiple phenotypes directly and independently from each other. This occurs when, for example, a gene product is a precursor of multiple physiological end-products. Indeed, such a mechanism is congruent with the mechanism of genetic confounding mentioned above. In contrast, vertical pleiotropy arises when a genetic variant affects one trait that in turn affects a second trait in a cascade-like manner, i.e., indirect causality between the gene and the second trait. In this case, two traits share a genetic etiology only because there exists a causal relation between the two. Both pleiotropic mechanisms lead to genetic correlation, but have different implications for our understanding of etiological mechanisms, risk assessment, disease prediction, and treatment and prevention strategies [73-75]. An important direction of future research is to distinguish between such mechanisms. 
Here, we find genetic correlations, but environmental correlations of nearly zero. Together, these findings suggest that insomuch as the associations between lifetime MDD and lifestyle are explained by causal effects, they also reflect a partially shared genetic etiology. Distinguishing between etiological and pleiotropic mechanisms, which need not be mutually exclusive, is no easy task, and caution should be applied in inferring causality or the absence thereof. However, we do note that under causality, we would have expected both genetic and environmental effects to translate from one trait to the other [65].

\section{Conclusions}

In summary, we find that phenotypic relations in the Dutch population between lifetime MDD and smoking behavior, physical inactivity, and obesity are partly driven by a shared genetic etiology. We demonstrate how estimates of genetic and environmental correlation can be derived in an extended twin pedigree design, with analyses conducted in the Mendel software. We show how pedigree analyses can serve as an alternative and feasible means to studying the shared etiology of disease and potential risk factors, and how genetic correlation estimates from extended twin pedigree data triangulate with similar estimates from molecular genetic data to benchmark pleiotropic effects.

Author Contributions: Conceptualization, D.I.B. and F.H.; software, Q.H., M.D.v.d.Z. and E.J.C.d.G.; data curation, Q.H. and F.H.; writing—original draft preparation, F.H. and D.I.B.; supervision, D.I.B., B.W.J.H.P. and Y.M.; visualization, F.H.; funding acquisition, D.I.B.; writing-review and editing, D.I.B., B.W.J.H.P., Y.M., Q.H., M.D.v.d.Z. and E.J.C.d.G. All authors have read and agreed to the published version of the manuscript.

Funding: This work was supported by the Royal Dutch Academy for Arts and Science (KNAW) Academy Professor Award (PAH/6635) to DIB; the Netherlands Organization for Scientific Research (NWO 480-15-001/674) and Biobanking and Biomolecular Resources Research Infrastructure (BBMRINL: 184.021.007; 184.033.111).

Institutional Review Board Statement: The study was conducted according to the guidelines of the Declaration of Helsinki, and approved by the medical ethical committee of the Amsterdam Universitair Medische Centra (UMC) (2014.449).

Informed Consent Statement: Informed consent was obtained from all subjects involved in the study.

Data Availability Statement: Data are available from the Netherlands Twin Register upon reasonable request (https:/ / tweelingenregister.vu.nl/information_for_researchers/working-with-ntr-data, accessed on 20 September 2021).

Acknowledgments: We warmly thank all twin families of the Netherlands Twin Register that contributed to this study.

Conflicts of Interest: The authors declare no conflict of interest.

\section{References}

1. Klein, D.N.; Riso, L.P. Psychiatric disorders: Problems of boundaries and comorbidity. In Basic Issues in Psychopathology; Guilford Press: New York, NY, USA, 1993; pp. 19-66.

2. Neale, M.C.; Kendler, K.S. Models of comorbidity for multifactorial disorders. Am. J. Hum. Genet. 1995, 57, 935-953. [PubMed]

3. Middeldorp, C.M.; Cath, D.C.; Van Dyck, R.; Boomsma, D.I. The co-morbidity of anxiety and depression in the perspective of genetic epidemiology. A review of twin and family studies. Psychol. Med. 1999, 35, 611-624. [CrossRef] [PubMed]

4. Falconer, D.S.; Mackay, T.F. Introduction to Quantitative Genetics, 4th ed.; Longman: Harlow, UK, 1996.

5. Solovieff, N.; Cotsapas, C.; Lee, P.H.; Purcell, S.M.; Smoller, J.W. Pleiotropy in complex traits: Challenges and strategies. Nat. Rev. Genet. 2013, 14, 483. [CrossRef] [PubMed]

6. Visscher, P.M.; Yang, J. A plethora of pleiotropy across complex traits. Nat. Genet. 2016, 48, 707-708. [CrossRef]

7. Watanabe, K.; Stringer, S.; Frei, O.; Mirkov, M.U.; de Leeuw, C.; Polderman, T.J.C.; van der Sluis, S.; Andreassen, O.A.; Neale, B.M.; Posthuma, D. A global overview of pleiotropy and genetic architecture in complex traits. Nat. Genet. 2019, 51, 1339-1348. [CrossRef]

8. Smoller, J.W.; Andreassen, O.A.; Edenberg, H.J.; Faraone, S.V.; Glatt, S.J.; Kendler, K.S. Psychiatric genetics and the structure of psychopathology. Mol. Psychiatry 2019, 24, 409-420. [CrossRef] 
9. Van Rheenen, W.; Peyrot, W.J.; Schork, A.J.; Lee, S.H.; Wray, N.R. Genetic correlations of polygenic disease traits: From theory to practice. Nat. Rev. Genet. 2019, 20, 567-581. [CrossRef]

10. The Brainstorm Consortium; Anttila, V.; Bulik-Sullivan, B.; Finucane, H.K.; Walters, R.K.; Bras, J.; Duncan, L.; Escott-Price, V.; Falcone, G.J.; Gormley, P.; et al. Analysis of shared heritability in common disorders of the brain. Science 2018, 360, eaap8757. [CrossRef]

11. Visscher, P.M.; Hill, W.G.; Wray, N.R. Heritability in the genomics era-Concepts and misconceptions. Nat. Rev. Genet. 2008, 9 , 255-266. [CrossRef]

12. Eaves, L.; Heath, A.; Martin, N.; Maes, H.; Neale, M.; Kendler, K.; Kirk, K.; Corey, L. Comparing the biological and cultural inheritance of personality and social attitudes in the Virginia 30,000 study of twins and their relatives. Twin Res. Hum. Genet. 1999, 2, 62-80. [CrossRef]

13. Maes, H.H.; Neale, M.C.; Martin, N.; Heath, A.C.; Eaves, L.J. Religious attendance and frequency of alcohol use: Same genes or same environments: A bivariate extended twin kinship model. Twin Res. Hum. Genet. 1999, 2, 169-179. [CrossRef]

14. Kendall, K.M.; Van Assche, E.; Andlauer, T.F.M.; Choi, K.W.; Luykx, J.J.; Schulte, E.C.; Lu, Y. The genetic basis of major depression. Psychol. Med. 2021, 1-14. [CrossRef] [PubMed]

15. Malhi, G.S.; Mann, J.J. Depression. Lancet 2018, 392, 2299-2312. [CrossRef]

16. Fluharty, M.; Taylor, A.E.; Grabski, M.; Munafo, M. The Association of Cigarette Smoking with Depression and Anxiety: A Systematic Review. Nicotine Tob. Res. 2017, 19, 3-13. [CrossRef] [PubMed]

17. de Geus, E.J. A genetic perspective on the association between exercise and mental health in the era of genome-wide association studies. Ment. Heal. Phys. Act. 2021, 20, 100378. [CrossRef]

18. Milaneschi, Y.; Simmons, W.K.; Van Rossum, E.F.C.; Penninx, B.W. Depression and obesity: Evidence of shared biological mechanisms. Mol. Psychiatry 2019, 24, 18-33. [CrossRef] [PubMed]

19. Cook, B.L.; Wayne, G.F.; Kafali, E.N.; Liu, Z.; Shu, C.; Flores, M. Trends in Smoking Among Adults with Mental Illness and Association Between Mental Health Treatment and Smoking Cessation. JAMA 2014, 311, 172-182. [CrossRef]

20. Mathew, A.R.; Hogarth, L.; Leventhal, A.M.; Cook, J.W.; Hitsman, B. Cigarette smoking and depression comorbidity: Systematic review and proposed theoretical model. Addiction 2016, 112, 401-412. [CrossRef]

21. Korhonen, T.; Broms, U.; Varjonen, J.; Romanov, K.; Koskenvuo, M.; Kinnunen, T.; Kaprio, J. Smoking behaviour as a predictor of depression among Finnish men and women: A prospective cohort study of adult twins. Psychol. Med. 2006, 37, 705-715. [CrossRef]

22. Pasco, J.A.; Williams, L.; Jacka, F.N.; Ng, F.; Henry, A.P.M.J.; Nicholson, G.; Kotowicz, M.; Berk, M. Tobacco smoking as a risk factor for major depressive disorder: Population-based study. Br. J. Psychiatry 2008, 193, 322-326. [CrossRef]

23. Berlin, I.; Covey, L.S.; Glassman, A.H. Smoking and Depression: A Co-morbidity. J. Dual Diagn. 2009, 5, 149-158. [CrossRef]

24. Teychenne, M.; Ball, K.; Salmon, J. Physical activity and likelihood of depression in adults: A review. Prev. Med. 2008, 46, 397-411. [CrossRef]

25. Lindwall, M.; Gerber, M.; Jonsdottir, I.H.; Börjesson, M.; Ahlborg, G. The relationships of change in physical activity with change in depression, anxiety, and burnout: A longitudinal study of Swedish healthcare workers. Health Psychol. 2014, 33, 1309-1318. [CrossRef]

26. Choi, K.W.; Zheutlin, A.B.; Karlson, R.A.; Wang, M.; Dunn, E.C.; Stein, M.B.; Karlson, E.W.; Smoller, J.W. Physical activity offsets genetic risk for incident depression assessed via electronic health records in a biobank cohort study. Depress. Anxiety 2020, 37, 106-114. [CrossRef]

27. Jia, H.; Zack, M.M.; Gottesman, I.I.; Thompson, W.W. Associations of Smoking, Physical Inactivity, Heavy Drinking, and Obesity with Quality-Adjusted Life Expectancy among US Adults with Depression. Value Health 2018, 21, 364-371. [CrossRef]

28. Achttien, R.; Van Lieshout, J.; Wensing, M.; Van Der Sanden, M.N.; Staal, J.B. Symptoms of depression are associated with physical inactivity but not modified by gender or the presence of a cardiovascular disease; a cross-sectional study. BMC Cardiovasc. Disord. 2019, 19, 95. [CrossRef]

29. Dennison, C.A.; Legge, S.E.; Bracher-Smith, M.; Menzies, G.; Escott-Price, V.; Smith, D.J.; Doherty, A.R.; Owen, M.J.; O’Donovan, M.C.; Walters, J.T.R. Association of genetic liability for psychiatric disorders with accelerometer-assessed physical activity in the UK Biobank. PLoS ONE 2021, 16, e0249189. [CrossRef]

30. Xu, Q.; Anderson, D.; Lurie-Beck, J. The relationship between abdominal obesity and depression in the general population: A systematic review and meta-analysis. Obes. Res. Clin. Pract. 2011, 5, e267-e278. [CrossRef] [PubMed]

31. Pereira-Miranda, E.; Costa, P.R.; Queiroz, V.A.; Pereira-Santos, M.; Santana, M.L.P. Overweight and Obesity Associated with Higher Depression Prevalence in Adults: A Systematic Review and Meta-Analysis. J. Am. Coll. Nutr. 2017, 36, 223-233. [CrossRef] [PubMed]

32. Luppino, F.S.; de Wit, L.; Bouvy, P.F.; Stijnen, T.; Cuijpers, P.; Penninx, B.W.J.H.; Zitman, F.G. Overweight, Obesity, and Depression: A Systematic Review and Meta-analysis of Longitudinal Studies. Arch. Gen. Psychiatry 2010, 67, 220-229. [CrossRef] [PubMed]

33. Mannan, M.; Mamun, A.; Doi, S.; Clavarino, A. Prospective Associations between Depression and Obesity for Adolescent Males and Females- A Systematic Review and Meta-Analysis of Longitudinal Studies. PLoS ONE 2016, 11, e0157240. [CrossRef] [PubMed]

34. Mannan, M.; Mamun, A.; Doi, S.; Clavarino, A. Is there a bi-directional relationship between depression and obesity among adult men and women? Systematic review and bias-adjusted meta analysis. Asian J. Psychiatry 2016, 21, 51-66. [CrossRef] [PubMed] 
35. Ligthart, L.; van Beijsterveldt, T.; Kevenaar, S.T.; de Zeeuw, E.; van Bergen, E.; Bruins, S.; Pool, R.; Helmer, Q.; van Dongen, J.; Hottenga, J.-J.; et al. The Netherlands Twin Register: Longitudinal Research Based on Twin and Twin-Family Designs. Twin Res. Hum. Genet. 2019, 22, 623-636. [CrossRef] [PubMed]

36. Bot, M.; Middeldorp, C.; de Geus, E.; Lau, H.M.; Sinke, S.M.; Van Nieuwenhuizen, B.; Smit, J.H.; Boomsma, D.I.; Penninx, B.W.J.H. Validity of LIDAS (LIfetime Depression Assessment Self-report): A self-report online assessment of lifetime major depressive disorder. Psychol. Med. 2016, 47, 279-289. [CrossRef]

37. Boomsma, D.I.; Helmer, Q.; Nieuwboer, H.A.; Hottenga, J.J.; de Moor, M.; Berg, S.V.D.; Davies, G.E.; Vink, J.M.; Schouten, M.J.; Dolan, C.V.; et al. An Extended Twin-Pedigree Study of Neuroticism in the Netherlands Twin Register. Behav. Genet. 2018, 48, 1-11. [CrossRef]

38. Kessler, R.C.; Andrews, G.; Mroczek, D.; Ustun, B.; Wittchen, H.-U. The World Health Organization Composite International Diagnostic Interview short-form (CIDI-SF). Int. J. Methods Psychiatr. Res. 1998, 7, 171-185. [CrossRef]

39. American Psychiatric Association. Diagnostic and Statistical Manual of Mental Disorders (DSM-5 (R.)); Psychiatric Association Publishing: Arlington, VA, USA, 2013.

40. Van Der Zee, M.D.; Helmer, Q.; Boomsma, D.I.; Dolan, C.V.; de Geus, E. An Extended Twin-Pedigree Study of Different Classes of Voluntary Exercise Behavior. Behav. Genet. 2020, 50, 94-104. [CrossRef]

41. Lange, K.; Papp, J.C.; Sinsheimer, J.S.; Sripracha, R.; Zhou, H.; Sobel, E.M. Mendel: The Swiss army knife of genetic analysis programs. Bioinformatics 2013, 29, 1568-1570. [CrossRef]

42. Lange, K.; Weeks, D.; Boehnke, M.; MacCluer, J.W. Programs for pedigree analysis: Mendel, Fisher, and dGene: Letters to the Editor. Genet. Epidemiol. 1988, 5, 471-472. [CrossRef] [PubMed]

43. Hopper, J. Review papers: Variance components for statistical genetics: Applications in medical research to characteristics related to human diseases and health. Stat. Methods Med. Res. 1993, 2, 199-223. [CrossRef] [PubMed]

44. Fisher, R.A. XV-The Correlation between Relatives on the Supposition of Mendelian Inheritance: The Correlation between Relatives on the Supposition of Mendelian Inheritance. Trans. R. Soc. Edinb. 1919, 52, 399-433. [CrossRef]

45. Eisenhart, C. The Assumptions Underlying the Analysis of Variance. Biometrics 1947, 3, 1. [CrossRef]

46. Weiss, K.M. Genetic Variation and Human Disease: Principles and Evolutionary Approaches; Cambridge University Press: Cambridge, UK, 1993.

47. Galván-Femenía, I.; Barceló-Vidal, C.; Sumoy, L.; Moreno, V.; de Cid, R.; Graffelman, J. A likelihood ratio approach for identifying three-quarter siblings in genetic databases. Heredity 2021, 126, 537-547. [CrossRef]

48. Statistics I Eurostat. Estimated Average Age of Young People Leaving the Parental Household by Sex. Available online: https: / / ec.europa.eu/eurostat/databrowser/view/yth_demo_030/default/table?lang=en (accessed on 26 May 2021).

49. Cohen, J.; Cohen, P.; West, S.G.; Aiken, L.S. Applied Multiple Regression/Correlation Analysis for the Behavioral Sciences; Routledge: London, UK, 2013.

50. Fedko, I.O.; Hottenga, J.-J.; Helmer, Q.; Mbarek, H.; Huider, F.; Amin, N.; Beulens, J.W.; Bremmer, M.A.; Elders, P.J.; Galesloot, T.E.; et al. Measurement and genetic architecture of lifetime depression in the Netherlands as assessed by LIDAS (Lifetime Depression Assessment Self-report). Psychol. Med. 2021, 51, 1345-1354. [CrossRef]

51. Sullivan, P.F.; Neale, M.C.; Kendler, K.S. Genetic Epidemiology of Major Depression: Review and Meta-Analysis. Am. J. Psychiatry 2000, 157, 1552-1562. [CrossRef]

52. Polderman, T.; Benyamin, B.; de Leeuw, C.; Sullivan, P.F.; Van Bochoven, A.; Visscher, P.; Posthuma, D. Meta-analysis of the heritability of human traits based on fifty years of twin studies. Nat. Genet. 2015, 47, 702-709. [CrossRef] [PubMed]

53. Wray, N.R. Using summary data from the Danish National Registers to estimate heritabilities for schizophrenia, bipolar disorder, and major depressive disorder. Front. Genet. 2012, 3, 118. [CrossRef] [PubMed]

54. Polubriaginof, F.C.; Vanguri, R.; Quinnies, K.; Belbin, G.M.; Yahi, A.; Salmasian, H.; Lorberbaum, T.; Nwankwo, V.; Li, L.; Shervey, M.M.; et al. Disease Heritability Inferred from Familial Relationships Reported in Medical Records. Cell 2018, 173, 1692-1704. [CrossRef] [PubMed]

55. Howard, D.M.; Adams, M.J.; Clarke, T.-K.; Hafferty, J.D.; Gibson, J.; Shirali, M.; Coleman, J.R.I.; Hagenaars, S.P.; Ward, J.; Wigmore, E.M.; et al. Genome-wide meta-analysis of depression identifies 102 independent variants and highlights the importance of the prefrontal brain regions. Nat. Neurosci. 2019, 22, 343-352. [CrossRef] [PubMed]

56. Yang, J.; Zeng, J.; Goddard, M.; Wray, N.R.; Visscher, P.M. Concepts, estimation and interpretation of SNP-based heritability. Nat. Genet. 2017, 49, 1304-1310. [CrossRef] [PubMed]

57. Li-Gao, R.; Boomsma, D.I.; de Geus, E.J.C.; Denollet, J.; Kupper, N. The Heritability of Type D Personality by an Extended Twin-Pedigree Analysis in the Netherlands Twin Register. Behav. Genet. 2021, 51, 1-11. [CrossRef]

58. Coventry, W.L.; Keller, M.C. Estimating the Extent of Parameter Bias in the Classical Twin Design: A Comparison of Parameter Estimates from Extended Twin-Family and Classical Twin Designs. Twin Res. Hum. Genet. 2005, 8, 214-223. [CrossRef]

59. Nivard, M.G.; Dolan, C.V.; Kendler, K.S.; Kan, K.-J.; Willemsen, G.; van Beijsterveldt, T.; Lindauer, R.J.L.; Van Beek, J.H.D.A.; Geels, L.M.; Bartels, M.; et al. Stability in symptoms of anxiety and depression as a function of genotype and environment: A longitudinal twin study from ages 3 to 63 years. Psychol. Med. 2015, 45, 1039-1049. [CrossRef] [PubMed]

60. Kendler, K.S.; Neale, M.C.; MacLean, C.J.; Heath, A.C.; Eaves, L.J.; Kessler, R.C. Smoking and Major Depression: A Causal Analysis. Arch. Gen. Psychiatry 1993, 50, 36-43. [CrossRef] [PubMed] 
61. Breslau, N.; Johnson, E.O.; Rhee, S.H.; Chase, G.A. Comorbidity of depression with levels of smoking: An exploration of the shared familial risk hypothesis. Nicotine Tob. Res. 2004, 6, 1029-1038. [CrossRef]

62. Dierker, L.C.; Avenevoli, S.; Stolar, M.; Merikangas, K. Smoking and Depression: An Examination of Mechanisms of Comorbidity. Am. J. Psychiatry 2002, 159, 947-953. [CrossRef] [PubMed]

63. Lyons, M.; Hitsman, B.; Xian, H.; Panizzon, M.S.; Jerskey, B.A.; Santangelo, S.; Grant, M.D.; Rende, R.; Eisen, S.; Eaves, L.; et al. A twin study of smoking, nicotine dependence, and major depression in men. Nicotine Tob. Res. 2008, 10, 97-108. [CrossRef]

64. McCaffery, J.M.; Niaura, R.; Swan, G.E.; Carmelli, D. A study of depressive symptoms and smoking behavior in adult male twins from the NHLBI twin study. Nicotine Tob. Res. 2003, 5, 77. [CrossRef]

65. De Moor, M.H.M.; Boomsma, D.I.; Stubbe, J.H.; Willemsen, G.; De Geus, E.J.C. Testing Causality in the Association Between Regular Exercise and Symptoms of Anxiety and Depression. Arch. Gen. Psychiatry 2008, 65, 897-905. [CrossRef]

66. Afari, N.; Noonan, C.; Goldberg, J.; Roy-Byrne, P.; Schur, E.; Golnari, G.; Buchwald, D. Depression and obesity: Do shared genes explain the relationship? Depress. Anxiety 2010, 27, 799-806. [CrossRef]

67. Choy, W.C.; López-León, S.; Aulchenko, Y.S.; Mackenbach, J.P.; Oostra, B.A.; van Duijn, C.M.; Janssens, A.C.J. Role of shared genetic and environmental factors in symptoms of depression and body composition. Psychiatr. Genet. 2009, 19, 32-38. [CrossRef] [PubMed]

68. Posthuma, D.; Boomsma, D.I. A Note on the Statistical Power in Extended Twin Designs. Behav. Genet. 2000, 30, 147-158. [CrossRef]

69. Keller, M.C.; Medland, S.E.; Duncan, L.E. Are Extended Twin Family Designs Worth the Trouble? A Comparison of the Bias, Precision, and Accuracy of Parameters Estimated in Four Twin Family Models. Behav. Genet. 2010, 40, 377-393. [CrossRef] [PubMed]

70. Choi, K.W.; Chen, C.-Y.; Stein, M.B.; Klimentidis, Y.; Wang, M.-J.; Koenen, K.C.; Smoller, J.W.; for the Major Depressive Disorder Working Group of the Psychiatric Genomics Consortium. Assessment of Bidirectional Relationships Between Physical Activity and Depression Among Adults: A 2-Sample Mendelian Randomization Study. JAMA Psychiatry 2019, 76, 399-408. [CrossRef]

71. Hodgkin, J. Seven types of pleiotropy. Int. J. Dev. Biol. 1998, 42, 501-505.

72. Paaby, A.; Rockman, M.V. The many faces of pleiotropy. Trends Genet. 2013, 29, 66-73. [CrossRef] [PubMed]

73. Pickrell, J.K.; Berisa, T.; Liu, J.Z.; Ségurel, L.; Tung, J.Y.; Hinds, D.A. Detection and interpretation of shared genetic influences on 42 human traits. Nat. Genet. 2016, 48, 709-717. [CrossRef] [PubMed]

74. Gratten, J.; Visscher, P. Genetic pleiotropy in complex traits and diseases: Implications for genomic medicine. Genome Med. 2016, 8, 1-3. [CrossRef]

75. Baselmans, B.M.; Yengo, L.; van Rheenen, W.; Wray, N.R. Risk in Relatives, Heritability, SNP-Based Heritability, and Genetic Correlations in Psychiatric Disorders: A Review. Biol. Psychiatry 2021, 89, 11-19. [CrossRef] [PubMed] 